

\section{Program Book}

$10^{\text {th }}$ Biennial Conference of Asian Association of Social Psychology 
The $10^{\text {th }}$ Biennial Conference of Asian Association of Social Psychology

Enhancing Quality of Life through Community Integrity and Cultural Diversity: Promoting Indigenous, Social, and Cultural Psychology

By: Asian Association of Social Psychology

Venue:

Universitas Gadjah Mada

Yogyakarta, August 21-24, 2013 
10th Biennial Conference of Asian Association of Social Psychology

Yogyakarta, August 21-24, 2013

\section{Contents}

Welcome .4

Chairperson of the 10th Biennial Conference of Asian Association of Social Psychology ............................................4

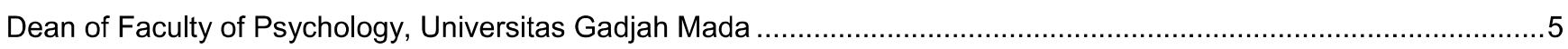

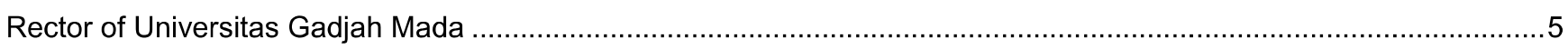

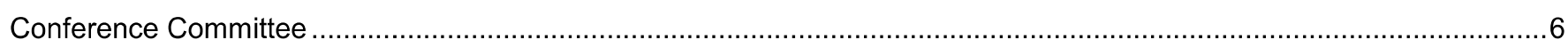

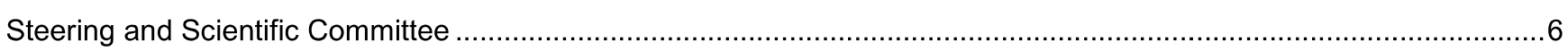

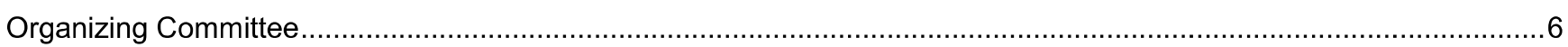

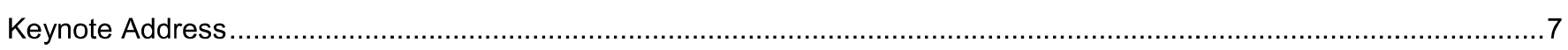

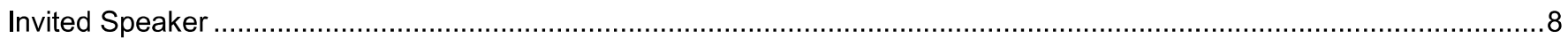

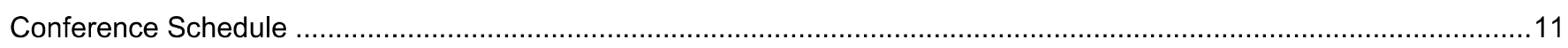

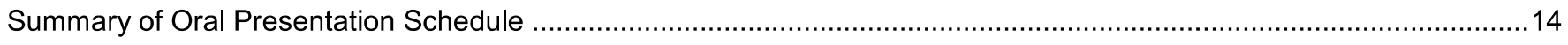

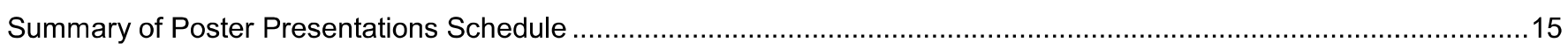

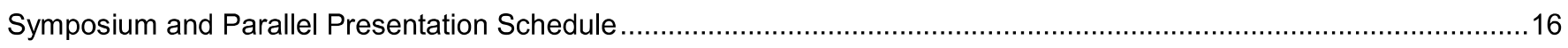

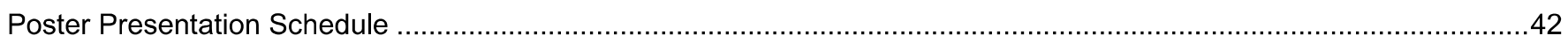

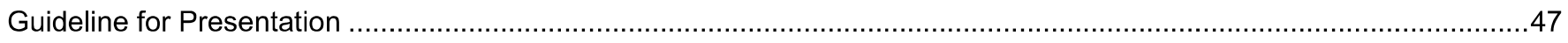

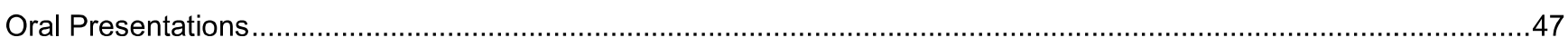

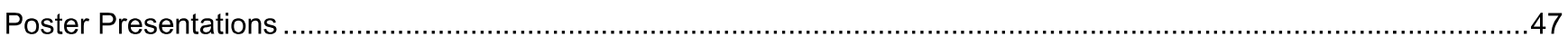

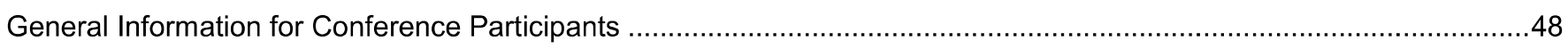

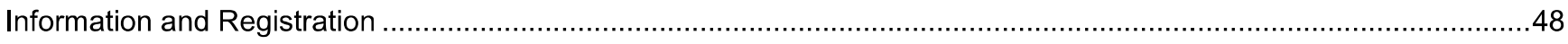

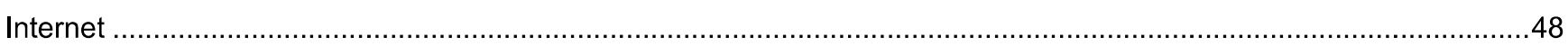

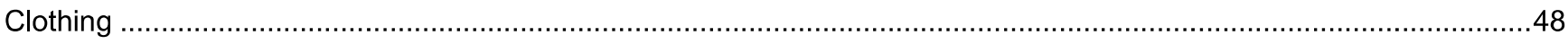

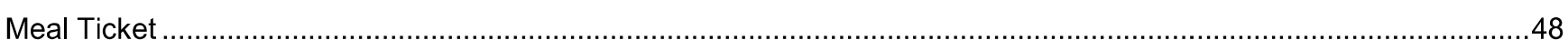

Social and Cultural Events …

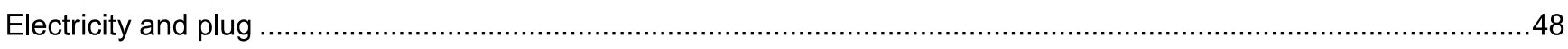

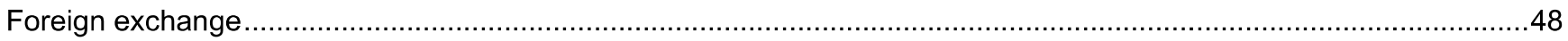

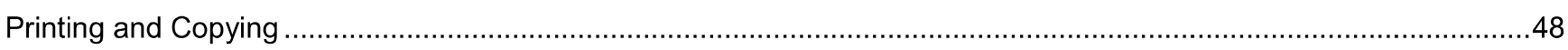

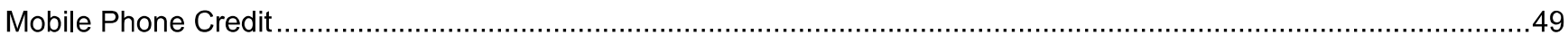

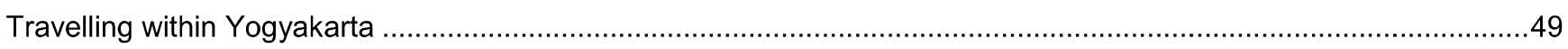

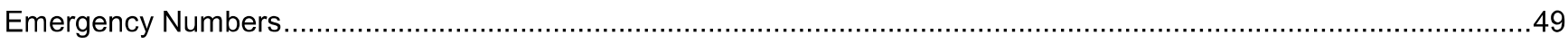

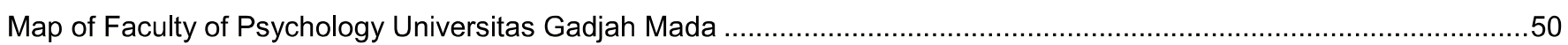

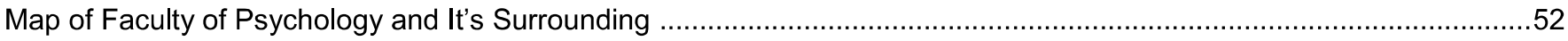




\section{Conference Committee}

\section{Steering and Scientific Committee}

\section{Chairperson}

Uichol Kim, Inha University, Korea

\section{Member}

Faturochman, Universitas Gadjah Mada, Indonesia Supra Wimbarti, Universitas Gadjah Mada, Indonesia Koentjoro, Universitas Gadjah Mada, Indonesia James Liu, Victoria University of Wellington, New Zealand Kwang Kuo Hwang, National Taiwan University, Taiwan Susumu Yamaguchi , University of Tokyo, Japan Hora Tjitra , Zhejiang University, China Wilman Dahlan Monsoer, Universitas Indonesia, Indonesia Hamdi Muluk, Universitas Indonesia, Indonesia Hendriati Agustiani, Universitas Padjajaran, Indonesia Augustinus Supratiknya , Universitas Sanata Dharma, Indonesia

\section{Organizing Committee}

\section{Chairperson}

Kwartarini Wahyu Yuniarti

\section{Local Arrangement}

Yopina Galih Pertiw

Haidar Buldan Thontowi

\section{Secretary}

Amitya Kumara

Rizqi Nur'aini A'yuninnisa

Orysa Noor Azizah

Yelfi Narulita

\section{Treasury}

Esti Hayu Purnamaningsih

Arifah Sindhika Putri

Diah Arum Ayuningtyas

Shenna Mentari Ayuningtyas

\section{General Contact Person}

Niken Rarasati

Kezia Ruth Fienta Tobing

\section{General Affair}

Adelia Khrisna Putri

Khoirunisa Nur Rahmatika

Insan Rekso Adiwibowo

Dibya Pradipta

Chandra Gupyta

Theodora Ruth Frisca

Sulasmi Sudirman

\section{Event Organizer}

Sentot Haryanto

Ammik Kisriyani

Arum Febriani

Nurul Aisya Beryllia

Candra Indraswari

Lusiana Yashinta

Rahajeng Dian Kurniasari

Diandra Isrodiyah Yulia Pramumardani

Malinda Wahyu Utami

Herawan Dwika Purba

Azka Nafirul Hasna
Dyaning Septa Arini

Scientific Networking

Thomas Dicky Hastjarjo

Subandi

\section{IT \& Media}

IJK Sito Meiyanto

Susanti

Banyu Wicaksono

Triadi Imron Rosyadi

Listyowening Mentari

Hanif Isnanto

Aulia Ariani

Nisita Daniswari

Alifan Cahyhana

Partnership \& Networking

Neila Ramdhani

Retno Suhapti

Lu'luatul Chizanah

Ratri Pratiwi

Ni Komang Meta SS

Hanike Kusumaningrum

Phaksi Seto

Acintya Ratna

Fikri Adi Budiman

Afra Imani Nasution

Syifana Rahma Addiyani

Noer Indah Kumala Indriyati

Dita Romadhoni

\section{Summer Course}

Hadi Sutarmanto

Helly Prajitno Soetjipto

Tina Afiatin

Ariana Marastuti

Idhei Kurnia Swasti

Ardian Praptomojati

Aulia Kusuma Wardani

Novita Dewi Anjarsari

Ekki Zazkia Lovabilita

Ali Araafi Akbar

Kurnia Putri Widiyaningsih Kiswanto
Annisa Azzahra Santifera

Hospitality

Wisjnu Martan

Noor Siti Rahmani

Wenty Marina Minza

Sri Kurnianingsih

Liaision Officers

Berta Dewi Nugraheni

Zafira Rahmania Nur S

Rifqi Fauzia

Galuh Adnindya

Krisna Sandy Pribadi

Amanda Rachmaniar

Tsabitah

Annas Nuril Qur'ani

Gisela Oktaria Efi

Adhila Rachma

Johanes Andriano Situmorang

Muhammad Fakhruzzaman

Muhamad Khosyi Ibrahim

Yunitha Ratnadilla

Septian Galih Widhi Asta

Syavira Martha Ristyana

Putri Pandi Anggita

Utami Lukita Lestari

Safira Tiara Dewi

Ni Made Rai Kistyanti

Ikfina Maufuriyah

Mumtaz Aji Wibowo

Vina Ardiani

Elvina Nurina Rakhmadita

Dina Ismi Hayati

Azzikra Nurul Fajri Aviantari

Yuliana Mukti Rahmawati

Gunisya Kartika Sari

Inas Zahra

Afnan Mufidah

Nefertiti Yunizare

Arlitadian Pratama

Mutiara Tita Trisnawijaya

Afif Saifi Hirzan

Aldila Winzariski Rahmawati
Melia Silmina

Sarah Khairunnisa

Hygna Dwipa Putri Husada

Aliya Nahra

Ester Kartika Sari

Anindya Phalita Padma

Heny Wijaya

Treviliana Eka Putri

Muhammad Harun Al Rasyid

Siti Maryam Wahyuni

Logistic \& equipment

Marnio Pudjono

Fuad Hamsyah

Wahyu Jati Anggoro

Dias Agung Wibowo

Delfian Tri Bandoro

Dimas Putra Utama

Bashar Maulana

Rofiq Iqbal

\section{Food \& Beverage}

Sri Hartati

Aisah Indati

Tunik Haryanti

Hanna Rahmawati

Caesar Astria Pusphita

Acommodation \& Transportation

MG. Adiyant

Edilburga WS

Slamet Widodo

Made Adi Suadnyana

Cendy Cahyo Rahmat

Ditta Nisa Rofa

Ayuning Galuh Resmi

Security \& medical

Campus Security and Safety Unit

Tourism

Hoshizora Tour and Travel 


\section{Keynote Address}

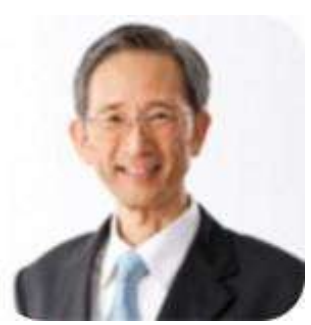

JH Park State-of-the-Art Address An Intellectual Journey Starting from Social Change

Ng Sik-Hung, City University of

Hongkong, SAR China

ssngsh@friends.cityu.edu.hk

Sik Hung $\mathrm{Ng}$ studied psychology and sociology at the University of Hong Kong, and social psychology at the University of Bristol, where he obtained his $\mathrm{PhD}$ in 1978. His academic career spans some 35 years, the last 20 as a full professor at Victoria University of Wellington (1992-2000) and the City University of Hong Kong (2000-2012), where he also served as the Department Head for varying periods from 1992 to 2006. The Royal Society of New Zealand elected Dr. Ng a Fellow in 1996, the first social psychologist to become a national academician of the country. He is also a Fellow of the British Psychological Society, and the International Association of Language and Social Psychology, of which he was the President (2004-2006).Dr Ng has had a long association with the Asian Association of Social Psychology marked by continuous service to the Asian Journal of Social Psychology and as an Executive Member of the Association. He has been an editorial board member of AJSP and, in recent years, a Senior Editor. With Shihui Han and James Liu, he coedited a couple of successful special issues for AJSP on the cultural brain and the development of Asian social psychology, respectively. $\mathrm{He}$ was the Association's President-Elect, then President, for a total of four years from 2005 and instrumental in revitalizing the Association's Newsletter, setting up the Summer School for PhD students, hosting the biennial conference in India for the first time, and institutionalizing the open election of the Presidency. In this current year (2013), he is the Principal of the $4^{\text {th }}$ Summer School and the Convenor of the Search Group for the new Chief Editor of AJSP.Dr Ng has published over 100 international journal articles covering social psychology (Asian Journal of SP, Basic and Applied SP, British JSP, European JSP, J Experimental SP, $J$ Personality and $S P$ ) and related fields (Ageing \& Society, Human Communication Research, J. Cross-Cultural P., J. Economic P., J. Environmental P., J. Language \& SP, J. Social Issues). His strongest research interests have been in power, language and communication, ageing, human values and biculturalism, on which he has also published five books and a number of book chapters. Several of his seminal articles were published in volumes edited by or in honour of Henri Tajfel.Dr Ng co-founded the New Zealand Institute for Research on Ageing, and was a member of the Provisional Minimum Wage Commission (PMWC) and the Central Policy Unit (CPU) of the Hong Kong SAR Government. The PMWC set up Hong Kong's historical statutory minimum wage in 2011 to lift the income of some 320,000 low-wage workers.

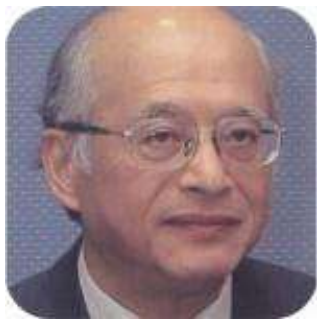

Culture-Inclusive Theories of Self and Social Interaction: The Approach of Multiple Philosophical Paradigms

Kwang Kuo Hwang, National Taiwan

University, Taiwan

kkhwang@ntu.edu.tw

Hwang Kwang-Kuo obtained his $\mathrm{PhD}$ in social psychology from the University of Hawaii, Honolulu, Hawaii. He is currently National Chair Professor at National Taiwan University, awarded by the Ministry of Education, Republic of China. He also serves as a National Policy Advisor to the President of Taiwan, Republic of China. Professor Hwang has endeavored to promote the indigenization movement in psychology and the social sciences in Chinese society since the early 1980s. He has published more than 100 articles on related issues in both Chinese and English in addition to eight books including Foundations of Chinese Psychology: Confucian Social Relations (English). He is president of the Asian Association of Indigenous and Cultural Psychology (2010-), past president of the Asian Association of Social Psychology (2003-2005), and was the Principal Investigator of the research project "In Search of Excellence for Indigenous Psychology," sponsored by the Ministry of Education, Republic of China (2000-2008).

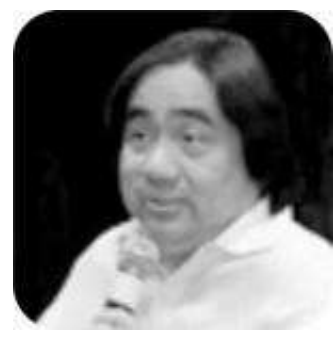

\section{Empowering and Improving the Well-being of Marginalized Persons in Indonesia: Challenges to Social Psychology \\ Irwanto, Universitas Atmajaya, Indonesia irwanto_i@yahoo.com}

Irwanto is a Professor of psychology in Universitas Katolik Atmajaya, Indonesia. He earned his Ph.D. from the Department of Child Development and Family Studies, Purdue University (1992). He has been an adjunct professor at the Department of Social Welfare, Faculty of Political and Social Sciences, Universitas Indonesia (1993-present); Department of Community Health, University of Illinois, Chicago (20012010); and at the Institute on Disability and Public Policy, American University, Washington DC (2013). He had been also an active member of negotiation/resolution of Ambon/Maluku Conflict in Langur, Tual Island (2002) and peace negotiation in Solo Conflict (2002). In addition, he had been a commissioner at the national Commission for Child Protection (1999-2002).Concerning to the social issues, he serves as the President of the National Coalition Against the Sexual Exploitation of Children - ECPAT International affiliate group (2005-present); CoDirector, Center for Child Protection, Faculty of Social and Political Science, Universitas Indonesia (2010-present); Head, Center for Disability Studies, Faculty of Social and Political science, Universitas Indonesia (2006-present); Chair, Steering Committee, Child-friendly City, Ministry of Women Empowerment and Child Protection (20112013); Member of Panel of Expert for HIV and AIDS, Ministry of Health (2013); and Bappenas Lead Consultant on Child protection for Medium term Development Plan (RPJMN) (2010-2014; 2015-2019). Regarding his dedication as social worker, he has been nominated in some awards from: Pacific Association of Social Work Education (APASWE) 2007 for outstanding contribution to social work education, the National AIDS Commission 2006 for pioneering work on Harm Reduction, and the National Narcotic Board 2005 for community based intervention among injecting drug users. 


\section{0th Biennial Conference of Asian Association of Social Psychology}

\section{Yogyakarta, August 21-24, 2013}

P78.1 Protective and Risk Factors Roles in Mt. Merapi Eruption Survivors' Psychological Condition - Sofia Retnowati (Indonesia)

P78.2 The Effect Psychological Contract Breach on Discretionary Work Behaviors Study in the Context of Safety- Yongjuan Li, Fangwei Li (China)

P78.3 The More Involved in Lead-Zinc Mining Risk the Less Frightened: A Psychological Typhoon Eye Prospective - Rui Zheng; Shu Li, Li-lin Rao (China)

P78.4 A Study on Safety Riding Behavior Applying Explicit and Implicit Measures - Muhammad Fikri Aflaha, Wilis Srisayekti (Indonesia)

P78.5 Judging the Objects Bestow Values Upon Users: An Assumption Perceptions towards Motorcycle Industry - Azhari Md Hashim (Malaysia)

Pactors of Students Movement's Participation in Indonesia from 1997 to 2012 - Andik Matulessy (Indonesia)

P79.3 Perception of Javanese Society to the Representation of Women in Parliament by Gender - Rifa Hidayah (Indonesia)

Pratama, Yohanes $K$. Herdiyanto (Indonesia)

P79.4 Identifying Salient Political Categories in a Legislative Debate: A Text-Mining Approach to Discourse Analysis - Cristina J. Montiel, Ma. Regina E. Estuar, Audris P. Umel (Philippines)

P79.5 Impact of Parent's Migration on the Emotional Quotient of the Young Adult offspring - Annaliza H. Sta. Ana (United Arab Emirates)

P79.6 Cognitive Style and Decision Making among Indian Politicians, Social Workers and Bureaucrats - Vikas Kamble (India) 


\title{
Perception of Javanese Society to The Representation of Women In Parliament By Gender
}

\author{
Rifa Hidayah \\ Psychology faculty, UIN Maulana Malik ibrahim Malang Indonesia
}

\begin{abstract}
Representation of women in parliament in Indonesia, particularly in Java are still marginalized, the number of women who sit in the parliaments of 1992 to 2009 is still very low. In 1992 the number of women as legislators $12.15 \%$, in 1999 the number of women as legislators $8.80 \%$. The phenomenon indicates that still discrimination in politics, where women as a majority of voters, but women as a minority in formal politics. Based on the issue, it is important to do research on the public perception of Java representation of women in parliament

The main purpose of this research was to find out, the difference between female and male perception of Java to the representation of women in parliament.

72 respondents of this study were selected from backgrounds Javanese culture. Data were collected by using a scale perception of women's representation in parliament, interviews and documentation. The perception of women's representation in parliament scale was applied as the main instruments in this study. The data of backgrounds Javanese culture and gender of the respondents were acquired through documentation.

Result of this study showed that: there were significant differences in the perception of male and female to the representation of women in parliament ( $p<$ 0.01). Female's perceptions of the representation of women in parliament was higher/positive than male.
\end{abstract}

Keywords: Women's representation in parliament, gender, culture Java

\section{Introduction}

Indonesian Women in politics still experiencing marginalization, the marginalization of women in politics can be seen, for example, the number of women who become Indonesian parliament 1999-2004 is 9.2\%, and from 2004 to 2009 , the number of women in parliament reached $11.8 \%$, whereas the number of women voters reached $57 \%$ percent. 
Quotas or other positive action strategies are generally viewed as compensation for structural barriers that prevent fair competition (Sadie, 2005). Although the start of 2004 has imposed a quota of $30 \%$ women in parliament/ legislature (as approved in the body of the Law No. 12 Year 2003 on General Elections, Article 65 Paragraph 1 confirms the nomination of women's representation in the legislature, the board provincial parliaments and parliaments of the district/city. "every political party contesting the election may nominate candidates for members of parliament, provincial legislature and the house of representatives district/city for each electoral district with due regard to the representation of women at least 30 percent .... " But the proportion of women who sit in parliament /legislature in Indonesia, including Java is still less when compared with men. This clearly shows that the representation of women in political practices (parliament) has not been completely fulfilled and the representation of women remains low.

The low representation of women in parliament like in the parliament and the council of representatives there are several factors that affect. There are internal and external barriers and cultural barriers to women's representation in parliament (Redjeki; 2003; Seda, 2004). The causes of women's underrepresentation are generally seen to reside in a combination of individual, cultural, and institutional inhibitors (Galligan \& Clavero, 2008).

The internal resistance is coming from women themselves, namely the willingness and readiness to take part in political parties. And external constraints derived from men and systems prevailing in the society, while the cultural barriers that patriarchal culture.

Java community as one of the ethnic groups that belong to the patrilineal (Koentjaraningrat, 1984), in which the Javanese culture is very dependent on the group (Mulder in Yuniarto, 2002), still adhered to assume the cultural patriarchal world of politics is a man's world, and the world women were knocked out of the world (Macioni, in Hilmy, 1989). Cultural factors also determine the existence of discrimination against women in politics. In general, if we look from the Javanese cultural values still view women in terms of rights, abilities, 
achievements, politics and so much lower than men. The gap between state representations of culture and the personal experiences of women is indicative of the gap between the state's effort to dictate women's experiences, and the kinds of decisions women take in their own lives (Hughes-Freeland, 2008). Based on the reality of the phenomenon and the author examines the public perception of the Java representation of women in parliament in terms of gender.

This study aimed to determine: (1). Javanese women's perceptions of the level of women's representation in parliament (2). The level of male's perception of Java to the representation of women in parliament (3). Differences in perceptions between men and women of Java to the representation of women in parliament.

\section{Research Methods}

\section{Variables}

The independent variables in this study were gender and culture of java. The dependent variable in this study is the perception of women's representation in parliament.

\section{Operational Concept}

Perceptions of women's representation in parliament are one assessment to the representation of women to enter into the world of practical politics and sat in parliament/legislature as parliaments/ assemblies consent of the governed. Perceptions of women's representation in parliament consisting of the internal constraints of women, the external constraints of women, cultural barriers and the electoral system and political organization

Gender is a biological and physiological differences between men and women were seen anatomically and reproduction.

\section{Participants}

The research was conducted in Malang East Java Indonesia, where more Javanese people live. Subjects in this study were 72 (36 males and 36 females). 


\section{Measures}

The scale of this research is the perception of the scale of representation of women, the author compiled based on the concept of the theory of perception and representation of women in parliament by Harvey and Smith (1977), Somasir, (2003), Nurdin ( 2003), and Redjeki (2003), The Cronbach alpha is 0.922 for the scale and have high difference height (r) more than 0.30 . The scale perception of political representation of women has a valid item with a significance level of $p$ $<0.05$ and is positively correlated.

\section{Result and Discussion}

The results showed that: T-test results $(t=0.000, \mathrm{p}<0.01)$ showed there are significant differences between men and women on the representation of women in parliament. Women are more positive rate of women who sit in parliament compared to men. Men or a woman who have a perception of gender. The primary influence on gender inequality in education is through culture and religion (Cooray \& Potrafke, 2011). Likewise men and women who have a negative perception of gender equality and traditional still have a tendency to judge women are inferior to men, including the representation of women in parliament. Individuals who have positive expectations of women who become representatives in the parliament will look, assess and perceive the representation of women in parliament in a positive way, it can even affect a positive attitude and support for women to be able to sit in parliament.

To date there are considerable differences between gender roles in various cultures, including the cultures of Indonesia. Cultural influences seen in terms of the opportunity to sit in parliament. This means that past experience subjects accustomed to living in an environment which is patrilineal cultures also greatly affect a person in perceiving an object. Where the perception can influence the attitudes and behavior because a person's perception of an organized process of interpreting the sensory stimuli and can affect the attitudes, thoughts and behaviors. 
In this regard it is clear that the culture of an impact on every human life, including cultural influences on women's opportunities to enter the world of politics. Social culture is one of the factors that affect a person's perception of women's representation, as well as a quota of $30 \%$ women in parliament. The effect of the gender quota law on the election and appointment of women hinged on a combination of three factors: the design of the law, the institutional context, and the agency of women's activists who monitored the quota's implementation (Kang, 2013).

\section{Conclusion}

Seeing this condition in the judgment of the researcher is actually the initial thing to do is political socialization to the whole society not to mention the presence of women as political education learning and gender perspective. Especially to eliminate negativity from the political image, so that women are able to understand what kind of politics that women are capable and brave actively involved in the political arena with high quality. So as to create equality of men and women as a political partner for a balance of public policies in all sectors. The project of increasing women's representation not only in the formal institutions of political power, but in the bureaucracy and in the structures of political parties themselves has to be taken up (Omvedt, 2005).

That political institution does not significantly influence education of girls (Cooray \& Potrafke, 2011). But Women's awareness of the importance of politics and the politics of education and the learning patterns and needs to be implemented to realize women's human rights, especially political rights that encourage women to know their rights and obligations as citizens and engage in the political process. With so many great hope for the women to increase representation in parliament not only in terms of quantity alone but rather in terms of quality.

The government needs to take strategic steps to increase women's representation in parliament through political socialization in the society at large, as do education and learning for all political gender perspective the people, both 
women and men to the regions. Socialize and political issues of the representation of women as a whole to the public, so that people understand and look objectively at the men and women who deserve to be qualified representatives. The government needs to create a system that holds elections gender.

\section{Research Limitation}

This study has several limitations that point the only research conducted in eastern Java preferably in Java that covers all regions of West Java, East Java and Central Java.

\section{References}

Cooray, A, and Potrafke, N. (2011), Gender inequality in education: Political institutions or culture and religion?. European Journal of Political Economy. Volume 27 (2), pp. 268-280

Galligan, Y., \& Clavero, S. (2008). Prospects for women's legislative representation in postsocialist europe. Gender and Society, Vol. 22 (2),pp.149-171.

Harvey, J.H., and Smith, W.P., (1977). Social Psychology: An Attribution Approach. Saint Louis Mosby.

Hilmy, U, et al., (1989). Politisi perempuan Indonesia: Meniti Karier Politik. P3W Unibraw Malang.

Hughes-Freeland, F. (2008). Gender, Representation, Experience: The Case of Village Performers in Java. The Journal of the Society for Dance Research, Vol. 26( 2), pp.140-167.

Kang, A (2013) The effect of gender quota laws on the election of women: Lessonsfrom Niger. Women's Studies International Forum . Vol 41, pp 94 -102 .

Koentjaraningrat. (1984). Kebudyaaan Jawa, Jakarta : Seri Etnografi No.2 Balai Pustaka.

Nurdin, N. (2003). Menggugat Marjinalisasi Perempuan di Parlemen. Http://situs.kesrepro.info/gendervaw/okt/2002/gendervaw01.htm. 
Omvedt, G. (2005). Women in governance in South Asia. Economic and Political Weekly, Vol. 40 (44/45), pp 4746-4752.

Paxton, P., \& Kunovich, S. (2003). Women's Political Representation: The Importance of Ideology. Social Forces, Vol. 82 (1), 87-11.3.

Redjeki, Sri. (2003). Kebijakan kementerian pemberdayaan perempuan dalam peningkatan keterwakilan perempuan dalam pengambilan keputusan. Semlokas.

Sadie, Y. (2005). Women in political decision-making in the SADC region. Women and Leadership. No. 65, pp.17-31.

Seda, A, (2004). dalam Cokorda yudistira, Perempuan Indonesia (masih) Minoritas dalam Politik. http://www.kompas.com/kompascetak/0207/22/dikbud/ pere36.htm.

Somasir, O. (2003). Pemilu 2004 Perempuan Masih Berada di Pinggiran. Jakarta: Sinar Harapan. 
